\title{
CHANGING TRENDS IN THE CAUSES OF MATERNAL MORTALITY OVER THE PAST 4 YEARS IN A TERTIARY CARE CENTRE
}

\author{
Darmalingam Uma1, Udayaruna Sundaram², Sudharsini Thayuman Santhakumar ${ }^{3}$
}

1Professor, Department of Obstetrics and Gynaecology, Mahatma Gandhi Memorial Government Hospital, KAPV Government Medical College, Trichy.

${ }^{2}$ Assistant Professor, Department of Obstetrics and Gynaecology, Mahatma Gandhi Memorial Government Hospital, KAPV Government Medical College, Trichy.

3Junior Resident, Department of Obstetrics and Gynaecology, Mahatma Gandhi Memorial Government Hospital, KAPV Government Medical College, Trichy.

\section{ABSTRACT}

\section{BACKGROUND}

Pre-eclampsia/Eclampsia is a very serious complication of pregnancy which is responsible for high maternal and perinatal mortality. Worldwide, it accounts for 50,000 maternal deaths annually.[1] In spite of several global and regional interventions and initiatives from governments and other concerned agencies, maternal mortality is still very high in India. This study was conducted to determine the changing trends in the causes of maternal deaths and incidence of maternal mortality associated with eclampsia.

\section{MATERIALS AND METHODS}

Ours is a retrospective study of maternal deaths over a period of 4 years from January 2012 to December 2015. Data pertaining to their age, parity, booking status, gestational age at time of delivery, and admission to death interval were also obtained from the records for analysis.

\section{RESULTS}

Eclampsia accounted for $35.08 \%$ of total maternal deaths, the commonest mode of death in eclampsia is pulmonary oedema. Death due to eclampsia commonly occurred in younger age group of 19-24 years and in primigravida. Eclampsia related deaths were most commonly seen in illiterate and unbooked cases. Maternal deaths were also very common in lower socioeconomic status.

\section{CONCLUSION}

Eclampsia has become the major cause of maternal mortality in MGMGH from unsupervised pregnancies and deliveries and delayed referral at the peripheral level. There is a need to educate and motivate the general public about antenatal care, educate the health personal at the peripheral level about the need for early referral so that we can avoid the morbidity and mortality of this condition.

\section{KEYWORDS}

Maternal Mortality, Pre-eclampsia/Eclampsia, Early Referral.

HOW TO CITE THIS ARTICLE: Uma D, Sundaram U, Santhakumar ST. Changing trends in the causes of maternal mortality over the past 4 years in a tertiary care centre. J. Evolution Med. Dent. Sci. 2017;6(21):1687-1690, DOI: 10.14260/Jemds/2017/371

\section{BACKGROUND}

Maternal death: "The death of a woman while pregnant or within 42 days of termination of pregnancy, irrespective of the duration and the site of the pregnancy, from any cause related to or aggravated by the pregnancy or its management but not from accidental or incidental causes." ICD-10, WHO, 1994.[1][2]

\section{Pregnancy-related Death}

"The death of a woman while pregnant or within 42 days of termination of pregnancy".

Financial or Other, Competing Interest: None.

Submission 18-10-2016, Peer Review 28-02-2017,

Acceptance 06-03-2017, Published 13-03-2017.

Corresponding Author:

Dr. Darmalingam Uma,

\#19/23, South Ramalinga Nagar,

$1^{\text {st }}$ Cross, Vayaloor Road,

Trichy-620017, Tamilnadu.

E-mail: eyedrrm@gmail.com

DOI: $10.14260 /$ jemds $/ 2017 / 371$
Direct causes from complications of pregnancy, delivery or their management e.g. haemorrhage, infection, toxaemia, obstructed labour and induced abortion. Indirect causes include medical conditions aggravated by pregnancy or delivery, e.g. heart diseases, hypertension, diabetes, hepatitis. Unrelated causes e.g. death from accidents, factors identified in maternal mortality categorised into four, namely 1 . Reproductive factors 2. Obstetric complications 3. Health service factors 4 . Socioeconomic factors.

Maternal mortality is an index to judge the health care by a country to the women population. It also reflects the educational and socioeconomic state of a country as well as public health consciousness.

Pregnancy, although considered a physiological state, carries risk of serious maternal morbidity and at times of death. Pre-eclampsia/Eclampsia is a very serious complication of pregnancy responsible for high maternal and perinatal mortality.

Eclampsia is an acute and life-threatening complication of pregnancy characterised by the appearance of tonic clonic seizures (convulsions), usually in a woman who has developed pre-eclampsia. Eclampsia includes convulsions and coma that happen during pregnancy that are not due to 
pre-existing or organic brain disorder. Eclampsia related complications include CVA (cerebrovascular accident), pulmonary oedema, renal failure, HELLP (haemolysis, elevated liver enzyme, and low platelet count) syndrome, DIC (Disseminated Intravascular Coagulation) and hepatic failure.[3]

Almost all maternal deaths (99\%) occur in developing countries.[1][2] India is among those countries, which has a very high maternal mortality ratio. The high number of maternal deaths in some areas reflects inequities in access to health services, and highlights the gap between the rich and the poor.[4,5.6] Despite the several global and regional interventions and initiatives from governments and other concerned agencies, maternal mortality continues to be very high in Sub-Saharan Africa and India, with eclampsia as a major cause in the recent years. Two major causes of maternal death in India are haemorrhage and eclampsia. This is also the major cause of maternal mortality in eastern part of India. $[7,8,9,10]$

\section{MATERIALS AND METHODS}

This retrospective hospital based study was carried out in Mahatma Gandhi Trichy Medical College and Hospital, a tertiary level health care referral centre in Trichy, South India. The study was conducted over a period of 4 years from January 2012 to December 2015. Out of 114 maternal deaths recorded over the study period, we retrieved data of 40 patients who died due to eclampsia. Data pertaining to their age, parity, booking status, gestational age at delivery, and time interval from admission to death were also obtained from the records for analysis. In the study period, all eclampsia cases were treated with magnesium sulphate.[11] The pregnant women with known seizure disorder were excluded from our study. Eclamptic mothers who did not have magnesium sulphate were also excluded from the study.

\section{RESULTS}

In the present study, out of 32806 deliveries, there were 114 maternal deaths. Out of 114 maternal deaths, 40 were eclampsia related. The most common causes of maternal mortality in our study are eclampsia (35.08\%), haemorrhage (14.03\%), sepsis (13.28\%), heart disease (6.64\%), pulmonary embolism (2.73\%), etc.

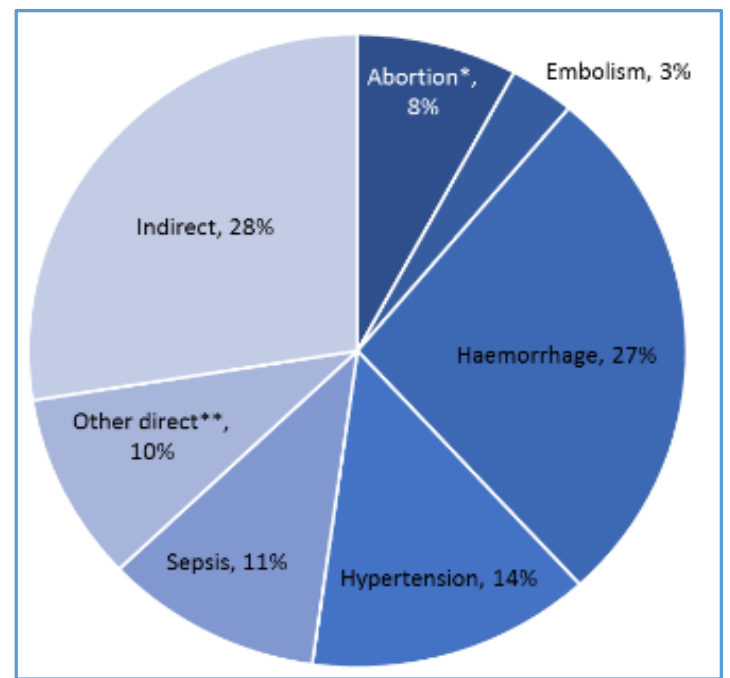

India Statistics in 2015 -causes of Maternal Mortality

\section{MATERNAL MORTALITY RATE (PER 100,000 LIVE BIRTHS)}

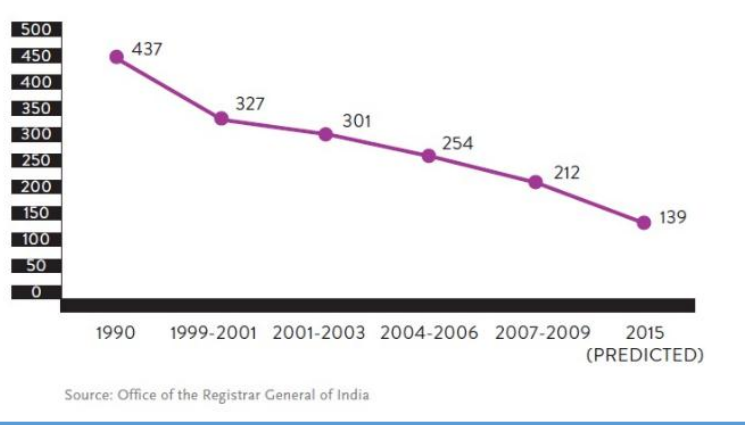

Distribution of Maternal Deaths According to Table 1

\begin{tabular}{|c|c|c|c|c|}
\hline Variables & $\mathbf{2 0 1 2}$ & $\mathbf{2 0 1 3}$ & $\mathbf{2 0 1 4}$ & $\mathbf{2 0 1 5}$ \\
\hline Socioeconomic status & & & & \\
\hline Upper & 0 & 0 & 0 & 0 \\
\hline Middle & 2 & 3 & 3 & 4 \\
\hline Lower & 33 & 27 & 22 & 20 \\
\hline Education & & & & \\
\hline Illiterate & 19 & 20 & 19 & 18 \\
\hline Primary education & 15 & 10 & 4 & 4 \\
\hline Secondary education & 1 & 0 & 2 & 2 \\
\hline Higher Secondary education & 0 & 0 & 0 & 0 \\
\hline Area of residence & & & & \\
\hline Urban & 3 & 2 & 2 & 1 \\
\hline Rural & 32 & 28 & 23 & 23 \\
\hline
\end{tabular}

Table 1. Distribution of Maternal Deaths (n=111) According to Sociodemographic Characteristics

\begin{tabular}{|c|c|c|c|c|c|c|}
\hline Variables & 2012 & 2013 & 2014 & 2015 & Total & $(\%)$ \\
\hline $\begin{array}{l}\text { Deaths } \mathrm{d} / \mathrm{t} \\
\text { eclampsia }\end{array}$ & 10 & 13 & 8 & 9 & 40 & \\
\hline$<19$ & 2 & 1 & 2 & 1 & 6 & $15 \%$ \\
\hline $19-25$ & 6 & 6 & 4 & 5 & 21 & $52.5 \%$ \\
\hline $26-29$ & 1 & 4 & 2 & 2 & 9 & $22.5 \%$ \\
\hline $30-34$ & 1 & 1 & 0 & 1 & 3 & $7.5 \%$ \\
\hline$>35$ & 0 & 1 & 0 & 0 & 1 & $2.5 \%$ \\
\hline \multicolumn{7}{|l|}{ Parity } \\
\hline Primigravida & 8 & 9 & 4 & 5 & 26 & $65 \%$ \\
\hline Multigravida (2-4) & 2 & 4 & 4 & 4 & 14 & $35 \%$ \\
\hline Grand multi (>4) & 0 & 0 & & 0 & 0 & - \\
\hline \multicolumn{7}{|c|}{$\begin{array}{c}\text { Table 2. Age and Parity Distribution in Eclamptic } \\
\text { Mothers who died During the Study Period (2012-2015) } \\
\text { shows that age below } 24 \text { years (76.57\%) and } \\
\text { Primigravidae (61.26\%) were Commonly Affected }\end{array}$} \\
\hline
\end{tabular}

\begin{tabular}{|c|c|c|c|c|c|c|}
\hline Variables & 2012 & 2013 & 2014 & 2015 & Total & $\%$ \\
\hline No. of deaths & 30 & 35 & 25 & 24 & 114 & \\
\hline Booked & 1 & 2 & 2 & 2 & 4 & $9.91 \%$ \\
\hline Unbooked & 17 & 16 & 24 & 21 & 22 & $90.09 \%$ \\
\hline \multicolumn{7}{|c|}{ Stage of pregnancy at time of death } \\
\hline 1st trimester & - & 3 & -1 & 1 & 4 & $3.5 \%$ \\
\hline $2^{\text {nd }}$ trimester & 2 & - & 1 & 1 & 4 & $3.5 \%$ \\
\hline $3^{\text {rd }}$ trimester & - & - & - & - & - & - \\
\hline Postpartum & 28 & 32 & 24 & 22 & 106 & $92.98 \%$ \\
\hline \multicolumn{7}{|c|}{ Time interval from admission to death } \\
\hline $0-6$ hrs. & 7 & 6 & 3 & 3 & 19 & $16.66 \%$ \\
\hline $7-12$ hrs. & 3 & - & 3 & 3 & 9 & $7.89 \%$ \\
\hline 13-24 hrs. & 3 & 3 & - & 3 & 9 & $7.89 \%$ \\
\hline$>24$ hrs. & 22 & 21 & 19 & 15 & 77 & $67.54 \%$ \\
\hline \multicolumn{7}{|c|}{$\begin{array}{l}\text { Table 3. Distribution of Maternal Deaths } \\
\text { by Delivery Related Characteristics }\end{array}$} \\
\hline
\end{tabular}


Maximum maternal deaths were seen in unbooked cases (Table 3). The majority of deaths occurred in the postpartum period and after 24 hours of admission (Table 3 )

\begin{tabular}{|c|c|c|c|c|c|}
\hline $\begin{array}{c}\text { Maternal } \\
\text { Death }\end{array}$ & $\mathbf{2 0 1 2}$ & $\mathbf{2 0 1 3}$ & $\mathbf{2 0 1 4}$ & $\mathbf{2 0 1 5}$ & $\begin{array}{c}\text { Total } \\
\text { During } \\
\text { Study } \\
\text { Period }\end{array}$ \\
\hline $\begin{array}{c}\text { Maternal } \\
\text { Deaths }\end{array}$ & 35 & 30 & 25 & 24 & 114 \\
\hline $\begin{array}{c}\text { Deaths due to } \\
\text { eclampsia }\end{array}$ & 13 & 10 & 8 & 9 & 40 \\
\hline $\begin{array}{c}\text { Contribution } \\
\text { to maternal } \\
\text { deaths } \\
\text { due to } \\
\text { eclampsia }\end{array}$ & $37.14 \%$ & $33.33 \%$ & $32 \%$ & 37.5 & $35.08 \%$ \\
\hline
\end{tabular}

Table 4. Year wise Incidence of Maternal Mortality due to Eclampsia in 5 years Study Period (2008-2012)

\begin{tabular}{|c|c|c|c|c|c|}
\hline Year & $\begin{array}{c}\text { Deaths d/t } \\
\text { eclampsia }\end{array}$ & $\begin{array}{c}\text { Pulmonary } \\
\text { oedema }\end{array}$ & CVA & $\begin{array}{c}\text { Renal } \\
\text { failure }\end{array}$ & Others \\
\hline 2012 & 10 & 6 & 1 & - & 3 \\
\hline 2013 & 13 & 4 & 4 & 1 & 4 \\
\hline 2014 & 8 & 3 & 1 & 1 & 4 \\
\hline
\end{tabular}

Table 5. Mode of Maternal Deaths in Eclamptic Mother (n=40) who died during the Study Period (2012-2015)

\section{DISCUSSION}

Maternal mortality is unacceptably high in developing countries. It has a severe impact on the family, community and eventually, the nation. The young surviving children left motherless are unable to cope with daily living and are at an increased risk of death. Reduction of maternal mortality is the objective of MDGs, especially in low income countries, where one in 16 women die of pregnancy related complications.

Hypertensive disorders of pregnancy are a major cause of maternal and foetal morbidity and mortality all over the world. Eclampsia is a well-recognised complication of hypertensive disorders of pregnancy.[7,8,9] In the present study, there were 114 maternal deaths out of 32806 deliveries in the past 4 years. Majority of patients in the present study belong to low socioeconomic group and were illiterate (Table 1). Most of them were from rural areas, had no antenatal visit and presented late with complication of eclampsia. It favours the observation that education, good antenatal care, early referral to intensive care units for standard care can reduce its incidence and complications. Due to lack of awareness, people do not seek medical advice at an early stage. As the majority of masses belong to low socioeconomic group, they do not report to hospitals even in late stages.[12,13]

Age and parity distribution of eclamptic mother shows that age below 19 to 25 years $(52.5 \%)$ was commonly affected. It is also seen from the present study that maximum maternal deaths occurred in primigravidae (65\%).[14] In our study, eclampsia related deaths were mainly seen in younger age group and in primigravidae. This is because of early marriage and early pregnancy. In rural India, due to social customs, teenage pregnancy is a very common practice. Low socioeconomic status and illiteracy are also important causes of early marriage and child birth.[12,13]

The majority of deaths in our study were in the postpartum (Table 5). Maximum deaths occurred after 24 hours of admission (73.87\%) and in unbooked (90.09\%) cases (Table 3). This is mainly due to late referral, poor antenatal checkup and transfer of moribund patients just before death to the tertiary hospital. A study done by Berhan et al also supports our findings.[15] Previously, obstetric haemorrhage was the major cause of maternal mortality in India at primary, secondary and tertiary care setups. However, recently, paradigm shift has been observed in tertiary health care setup like medical colleges. In our study, it was observed that eclampsia contributes to $43.57 \%$ of all maternal deaths, whereas eclampsia causes $12 \%$ of all global maternal deaths. A study from Eastern India (West Bengal) by Sarkar et al also supports our result.[16]

While reviewing the mode of deaths in eclampsia, it was observed that pulmonary oedema is the commonest cause of death in eclampsia in our study. Incidence of pulmonary oedema is higher in eclampsia due to leaky pulmonary capillaries. In UK, commonest cause of death in eclampsia is CVA which is different from our study.[17,18]

Early detection and referral at the peripheral level and strengthening of referral system is of utmost importance. The concept of atypical pre-eclampsia which is even in the absence of proteinuria the syndrome of pre-eclampsia must be considered when gestational hypertension is present in association with impending signs and symptoms or thrombocytopenia, haemolysis or elevated liver enzymes must be emphasised. Eclampsia contributes significantly to maternal mortality in India. $[7,8,9]$

\section{CONCLUSION}

Our study has helped in identifying the actual cause of maternal deaths and deficiencies in health care delivery system that might contribute to formulating preventive measures to reduce pregnancy related deaths. Efforts should be made at community level, district level and state level to improve facilities and social infrastructures that will directly or otherwise minimise the occurrence of eclampsia. To reduce the maternal mortality and morbidity, the main thrust should be on implementing basic and comprehensive emergency obstetrics care. Most deaths can be avoided by improving socioeconomic status; level of education; quality of patient's nutrition; good antenatal, intranatal and postnatal care; early referral, and quick and well-equipped transport facilities.

\section{REFERENCES}

[1] Countdown to 2015 for maternal, newborn and child survival: accountability for maternal, newborn and child survival. Geneva: World Health Organisation 2013.

(http//www.countdown2015mnch.org/documents/2 013Report/Countdown_2013-

Updates_noprofiles.pdf).

[2] Trends in maternal mortality: 1990-2010—estimates developed by WHO, UNICEF, UNFPA and the World Bank 2012.

[3] Micheal BB. Eclampsia. Emer Med J 2000;74:1-10. 
[4] World Health Organization \& UNICEF, author. Countdown to 2015 Decade Report (2000-2010): Taking Stock of Maternal, New born and Child Survival. Geneva: WHO and UNICEF 2010. [http//www.childinfo.org/files/countdownReport200 0-2010.pdf]

[5] Bangal V, Giri P, Garg R. Maternal mortality at a tertiary care teaching hospital of rural India: a retrospective study. Int J Biol Med Res 2011;2(4):1043-6.

[6] Mullick SS, Serle E. Achieving millennium development goals 4 and 5: a snapshot of life in rural India. BJOG 2011;118(Suppl 2):104-7.

[7] Goldenberg RL, McClure EM, Macguire ER, et al. Lessons for low-income regions following the reduction in hypertension-related maternal mortality in high-income countries. Int J Gynaecol Obstet 2011;113(2):91-5.

[8] Danso KA, Opare-Addo HS. Challenges associated with hypertensive disease during pregnancy in low-income countries. Int J Gynaecol Obstet 2010;110(1):78-81.

[9] Dasari P, Habeebullah S. Maternal mortality due to hypertensive disorders of pregnancy in a tertiary care center in southern India. Int J Gynaecol Obstet 2010;110(3):271-3.

[10] Engle PL, Fernald LC, Alderman H, et al. Strategies for reducing inequalities and improving developmental outcomes for young children in low-income and middle-income countries. Lancet 2011; 378(9799): 1339-53.
[11] Saha S, Ghosh S, Ganguly RP, et al. Comparative study of efficacy of magnesium sulphate and diazepam in the management of eclampsia in a peripheral rural medical college (A cross over study of 440 cases). J Obstet Gynecol Ind 2002;52:69-72.

[12] Yaliwal RG, Jaju PB, Vanishree M. Eclampsia and perinatal outcome: a retrospective study in a teaching hospital. J of Clin and Diagn Res 2011;5(5):1056-9.

[13] Kaur P. A clinical study in eclampsia on a referral hospital. J South Asian Feder Obst Gnaecol 2012;4(2):113-5.

[14] Dutta MR, Pant L, Kabiraj M, et al. Magnesium sulphate in eclampsia: a safe, efficient and cost effective approach. J Obstet Gynecol Ind 2002;52(3):65-8.

[15] Berhan Y, Berhan A. Commentary: reasons for persistently high maternal and perinatal mortalities in Ethiopia: part III- perspective of the "Three delays" model. Ethiop J Health Sci 2014;24:137-48.

[16] Sarkar M, Basak S, Mondal SK, et al. Maternal mortality associated with eclampsia in an Indian medical college: a four year retrospective study. J Med Med Sci 2013;4(10):394-8.

[17] Tuffnell DJ, Jankowicz D, Lindow SW, et al. Outcomes of severe pre-eclampsia/ eclampsia in Yorkshire 1999/2003. Br J Obstet Gynecol 2005;112(7):875-80.

[18] Lewis G, ed. The Confidential Enquiry into maternal and Child Health (CEMACH). Saving mothers' Lives: reviewing maternal deaths to make motherhood safer2003-2005. The Seventh report on Confidential Enquiries into maternal deaths in the United Kingdom. CEMACH, London 2007. 